\title{
Assessing the yield, microstructure, and texture properties of miniature Chihuahua-type cheese manufactured with a phospholipase $A_{1}$ and exopolysaccharide-producing bacteria
}

\author{
N. Trancoso-Reyes, ${ }^{*}$ N. Gutiérrez-Méndez, ${ }^{* 1}$ D. R. Sepulveda, $†$ and L. R. Hernández-Ochoa* \\ *Universidad Autónoma de Chihuahua, Facultad de Ciencias Químicas, 31125 Chihuahua, Chihuahua, Mexico \\ †Centro de Investigación en Alimentación y Desarrollo, A. C., Cuauhtemoc, 31570 Chihuhua, Mexico
}

\begin{abstract}
Chihuahua cheese or Mennonite cheese is one of the most popular and consumed cheeses in Mexico and by the Hispanic community in the United States. According to local producers the yield of Chihuahua cheese ranges from 9 to $9.5 \mathrm{~kg}$ of cheese from $100 \mathrm{~kg}$ of milk. Cheese yield is a crucial determinant of profitability in cheese-manufacturing plants; therefore, different methods have been developed to increase it. In this work, a miniature Chihuahua-type cheese model was used to assess the effect of a phospholipase $\mathrm{A}_{1}\left(\mathrm{PL}-\mathrm{A}_{1}\right)$ and exopolysaccharide (EPS)-producing bacteria (separately and in combination) on the yield, microstructure, and texture of cheese. Four different cheeses were manufactured: cheese made with PL-A $A_{1}$, cheese made with EPS-producing bacteria, cheese with both PL-A $\mathrm{A}_{1}$ and EPS-producing bacteria, and a cheese control without PL-A $\mathrm{A}_{1}$ or EPS-producing bacteria. The compositional analysis of cheese was carried out using methods of AOAC International (Washington, DC). The actual yield and moisture-adjusted yield were calculated for all cheese treatments. Texture profile analyses of cheeses were performed using a texture analyzer. Micrographs were obtained by electron scanning microscopy. Fifty panelists carried out sensorial analysis using ranking tests. Incorporation of EPS-producing bacteria in the manufacture of cheese increased the moisture content and water activity. In contrast, the addition of PL- $\mathrm{A}_{1}$ did not increase fat retention or cheese yield. The use of EPS alone improved the cheese yield by increasing water and fat retention, but also caused a negative effect on the texture and flavor of Chihuahua cheese. The use of EPS-producing bacteria in combination with PL- $\mathrm{A}_{1}$ improved the cheese yield and increased the moisture and fat content. The cheeses with the best flavor and texture were those manufactured with PL- $\mathrm{A}_{1}$ and the
\end{abstract}

Received January 25, 2013.

Accepted October 20, 2013.

${ }^{1}$ Corresponding author: ngutierrez@uach.mx cheeses manufactured with the combination of PL-A1 and EPS-producing culture.

Key words: Chihuahua cheese, cheese yield, phospholipase, exopolysaccharide-producing bacteria

\section{INTRODUCTION}

Cheese yield is a crucial determinant of profitability in cheese-manufacturing plants. This process variable is affected by several different factors, such as the characteristics of milk (i.e., composition, milk quality, and SCC, among others) and by the cheese-making conditions (i.e., homogenization, standardization, pasteurization, coagulant type, starter cultures, vat design, and curd firmness at cutting, among others). Due to its economic impact, several different methods have been developed through the years to increase yield (Barbano et al., 1991; Guinee et al., 2006; Banks, 2007; Fagan et al., 2007). These methods include the incorporation of whey proteins, UF of cheese milk (Abd El-Gawad and Ahmed, 2011), increment of the protein-to-fat ratio (Guinee et al., 2007), use of ultrasound on cheese milk (Bermúdez-Aguirre and Barbosa-Cánovas, 2010), treatment of cheese milk with phospholipase $A_{1}\left(\mathbf{P L}-\mathbf{A}_{\mathbf{1}}\right.$; De Maria et al., 2007), and use of exopolysaccharide (EPS)-producing bacteria (Costa et al., 2012).

The use of phospholipases is common in the production of vegetable oil, starch, and baking ingredients, but their use in the dairy industry had not been considered until recently (De Maria et al., 2007). Nielsen (2001) patented a process to produce Mozzarella cheese from milk treated with phospholipase $\mathrm{A}_{1}, \mathrm{~A}_{2}$, and $\mathrm{B}$. Five years later, Patkar et al. (2006) patented a fungal phospholipase that was modified to alter its substrate specificity, obtaining an enzyme with phospholipase activity and reduced activity on triglycerides. In the same year, Lilbæk et al. (2006) used a PL-A from Fusarium venenatum in the manufacture of Mozzarella cheese, reporting an increase in the cheese yield $(3.2 \%)$ due to moisture and fat retention. Some indications exist that phospholipases detach bilayer fragments from the milk fat globule membrane (MFGM), where about $60 \%$ of 
milk phospholipids occur, modifying the membrane surface properties and decreasing the $\zeta$-potential (Keenan and Mather, 2006; Lilbæk et al., 2007; Bourlieu et al., 2012). However, the effect of PL- $A_{1}$ on the MFGM and its influence during the manufacture of cheese is not yet fully understood.

On the other hand, a growing interest exists nowadays on the use of EPS-producing bacteria to increase cheese yield, mainly because of the generally recognized as safe (GRAS) status of these microorganisms, and because its industrial use is easy and inexpensive (Lin and Chang Chien, 2007). The use of EPS-producing bacteria to increase cheese yield has been explored in different types of cheeses, such as half-fat Cheddar cheese (Dabour et al., 2006; Costa et al., 2010), Mozzarella (Petersen et al., 2000), and fresh cheese (Jiménez-Guzmán et al., 2009). It is believed that bacterial polysaccharides increase the cheese yield by trapping the fat and non-fat milk solids into the web of EPS and the casein matrix (Petersen et al., 2000; Dabour et al., 2006; Jiménez-Guzmán et al., 2009; Costa et al., 2010). Bacterial polysaccharides also increase the moisture content of the cheese, although the chemical interaction between water and polysaccharides is very weak; therefore, water is just physically retained into the web of polysaccharides (Costa et al., 2012). It is known that the properties of microbial EPS depend on their composition, structure, charge, linkage between units, and presence of repeated side chains (Duboc and Mollet, 2001). However, it is still not clear how these polysaccharides interact with certain milk components and the kind of interactions that occur between EPS and cheese components.

One of the most popular and consumed cheeses in Mexico is the Chihuahua cheese or Mennonite cheese (Tunick et al., 2008). The history of Chihuahua cheese is closely related to Mennonite communities who migrated from Canada to Chihuahua, Mexico, in 1922 (Hansen, 2005). The manufacturing process of Chihuahua cheese resembles that of Cheddar cheese, although its texture is more similar to fresh Colby cheese. Chihuahua cheese is typically yellow and turns golden yellow when ripe, it has a semi-hard and sliceable consistency, and its sensory characteristics are similar to that of 1-mo-old Cheddar cheese (Gutiérrez-Méndez and Nevárez-Moorillon, 2009). Little information exists about the yield of Chihuahua cheese, but according to local producers, it ranges from 9 to $9.5 \mathrm{~kg}$ of cheese from $100 \mathrm{~kg}$ of milk.

The State of Chihuahua is located in a desert region in Mexico, where milk production is expensive and, thus, the profitability of cheese production is low. For this reason, a major concern for local cheese makers is the cheese yield and the alternatives to increase it. In this work, the effect of 2 combined methods (cheese milk treated with PL- $\mathrm{A}_{1}$ and the incorporation of an EPS-producing culture) on the yield, texture, and microstructure of cheese was explored. The research was carried out using miniature versions of Chihuahua cheese to improve the reproducibility of experimental cheeses. Miniature model cheeses are similar to pilot plant cheeses and can be manufactured in the laboratory under controlled conditions, minimizing manufacturing variations and reducing microbiological contamination (Shakeel-Ur-Rehman et al., 1998, 1999, 2001; Hynes et al., 2000, 2003; Milesi et al., 2007, 2008).

\section{MATERIALS AND METHODS}

\section{Microorganisms and Phospholipase}

Two different cultures of lactic acid bacteria (LAB) were used in this study: a starter culture and an EPSproducing culture. The starter culture (MM101-LY025; Danisco Deutschland GmbH, Niebüll, Germany) used for the manufacture of Chihuahua cheese included strains of Lactococcus lactis ssp. lactis, Lactococcus lactis ssp. cremoris, and Lactococcus lactis ssp. lactis var. diacetylactis. The EPS-producing culture (Y 470E; Sacco International, Cadorago, Italy) had a strain of Streptococcus thermophilus (ropy EPS-producing streptococci) and a strain of Lactobacillus delbrueckii. The phospholipase used in this study was PL- $\mathrm{A}_{1}$ (phosphatidylcholine 1-acylhydrolase; EC 3.1.1.32) from Aspergillus oryzae. The PL- $\mathrm{A}_{1}$ solution (YieldMAX; Chr. Hansen A/S, Hørsholm, Denmark) had the strength of 2,300 Lecitase units (LEU)/mL and was added into the milk at a rate of 5 LEU per gram of milk fat, according to the specifications of the manufacturer.

\section{Determination of the Effect of PL-A, on Bacterial Growth and EPS Production}

Eight conical tubes (Falcon; BD, Franklin Lakes, NJ) with $50 \mathrm{~mL}$ of sterile M17 broth were inoculated with EPS-producing bacteria, and then $3.25 \mu \mathrm{L}$ of PL- $\mathrm{A}_{1}$ (YieldMAX; Chr. Hansen A/S) was added to 4 of these tubes. The final concentration of PL- $\mathrm{A}_{1}$ in the broths was $15 \mathrm{LEU} / 100 \mathrm{~mL}$ of M17 broth. Broths were poured into wells of sterile microplates (96-well U-bottom shape), adding $250 \mu \mathrm{L}$ of broth in each well. Microplates were incubated at $37^{\circ} \mathrm{C}$ in a microplate reader (ELx808; BioTek Instruments Inc., Winooski, VT), and changes in optical density at a wavelength of $630 \mathrm{~nm}\left(\mathrm{OD}_{630}\right)$ were monitored every $60 \mathrm{~min}$ for $24 \mathrm{~h}$. Data collected were subjected to nonlinear regression analysis using the Baranyi model (Baranyi and Roberts, 1994) with the software DMFit (version 2.1; Institute of Food Re- 
search, Norwich, UK) to obtain the growth parameters of the EPS-producing culture.

Production of EPS was measured in the 8 M17 broths immediately after inoculation (initial polysaccharide concentration) and after incubation at $37^{\circ} \mathrm{C}$ for $24 \mathrm{~h}$ (final concentration). Five milliliters from each broth was heated at $80^{\circ} \mathrm{C}$ for $15 \mathrm{~min}$ and then cooled and centrifuged at $1,700 \times g$ for $15 \mathrm{~min}$ at $20^{\circ} \mathrm{C}$. Ten milliliters of ethanol $(80 \%)$ was added to the supernatants obtained, which were centrifuged again at $1,700 \times g$ for $15 \mathrm{~min}$ at $20^{\circ} \mathrm{C}$. These supernatants were analyzed for their sugar content according the method described by DuBois et al. (1956) and expressed as glucose equivalents. The polysaccharide yield was calculated by subtracting the initial polysaccharide concentration from the final concentration.

\section{Manufacture of Miniature Chihuahua-Type Cheese}

Four different types of cheeses were manufactured in this study: (a) control cheese without addition of PL- $\mathrm{A}_{1}$ and (or) EPS-producing bacteria, (b) cheese made with milk treated with PL-A (YieldMAX; Chr. Hansen A/S), (c) cheese manufactured with an EPS-producing culture (Y 470E; Sacco International), and (d) cheese made with milk treated with PL-A1 and inoculated with an EPS-producing culture. The PL- $\mathrm{A}_{1}$ was added in a concentration of $15 \mathrm{LEU} / 100 \mathrm{~g}$ of milk, whereas EPS-producing bacteria were inoculated by adding $1 \%$ (vol/vol) of milk previously fermented with this culture. Each treatment was repeated 4 times in different batches on different days, using a similar procedure to the one described by Shakeel-Ur-Rehman et al. (1998). Portions of $250 \mathrm{~g}$ of standardized (3\% fat) milk were placed in four $500-\mathrm{mL}$ glass beakers and pasteurized at $63^{\circ} \mathrm{C}$ for $30 \mathrm{~min}$. Milk portions were cooled to $32^{\circ} \mathrm{C}$ and inoculated with freeze-dried starter culture (MM101LY025; Danisco Deutschland GmbH), the EPS culture, and (or) the PL- $\mathrm{A}_{1}$. The milk was incubated for $1 \mathrm{~h}$ at $32^{\circ} \mathrm{C}$; then, $100 \mu \mathrm{L}$ of $4.6 \mathrm{M} \mathrm{CaCl}_{2}$ was added (to obtain a final concentration in the milk of $1.84 \mathrm{mM}$ ) and 13.75 $\mu \mathrm{L}$ of chymosin [strength 1,000 international milk-clotting units (IMCU)/mL; CHY-MAX; Chr. Hansen A/S] was added. After $1 \mathrm{~h}$ of incubation at $32^{\circ} \mathrm{C}$, curds were cut with a stainless steel spatula into small cubes of 0.8 $\mathrm{cm}^{3}$, held for $10 \mathrm{~min}$, and then stirred at $150 \mathrm{rpm}$ for 60 min in an orbital shaker (DS-500; VWR Scientific Products, Thorofare, NJ) at $32^{\circ} \mathrm{C}$. Afterward, whey was removed using a strainer and the curd was warmed to $38^{\circ} \mathrm{C}$ in a water bath until the $\mathrm{pH}$ reached 5.6. The curd was then salted with $1 \% \mathrm{NaCl}$ (wt/wt) and transferred into polypropylene tubes (4.3-cm diameter and 9 -cm height). The tubes were centrifuged for $30 \mathrm{~min}$ at $1,700 \times g$ at room temperature. The expelled whey was drained, and the curd was again centrifuged for $60 \mathrm{~min}$ at $1,700 \times g$ at room temperature. Mini-cheeses were removed from the tubes and refrigerated $\left(4^{\circ} \mathrm{C}\right.$ at $75 \%$ relative humidity) without packing for $48 \mathrm{~h}$ to adjust the moisture content. Finally, mini-cheeses were wiped with tissue paper (to remove excess moisture), packed in hermetic polyethylene bags $(16.5 \times 14.9 \mathrm{~cm})$, and stored at $3{ }^{\circ} \mathrm{C}$ for 1 wk before their analysis.

\section{Compositional Analysis of Cheeses}

Whey and cheese samples were analyzed (in triplicate) for moisture, protein, fat, and ash content using AOAC International (1998) methods (method 926.08, $991.22,905.02$, and 935.42 , respectively). The $\mathrm{pH}$ was obtained using AOAC International (1998) method 981.12 with a pH meter (Pinnacle; Corning Inc., Corning, NY). The measurement of ionic calcium in whey samples was performed using an ion-selective electrode (HI 4104; Hanna Instruments Inc., Woonsocket, RI), as described by Nielsen (2010).

\section{Determination of Cheese Yield}

The weight of the milk, curd, and cheese was measured during manufacture of the miniature cheeses using an analytical balance (0.01-mg resolution). The weight of the whey recovered from the drainage of curd plus the weight of the whey obtained from the 2 centrifugation steps was considered as the total weight of whey. Miniature cheeses were weighed before their packaging in plastic bags and $10 \mathrm{~d}$ after their manufacture. Actual yield $(Y a)$ was calculated using the weight of the cheeses after $10 \mathrm{~d}$ of manufacture.

The percentage of milk fat lost in whey $(\% F L)$ was calculated with the following formula:

$\% F L=\frac{\text { weight of whey } \times \text { proportion of fat in whey } \times 100}{\text { weight of milk } \times \text { proportion of fat in milk }}$.

The $Y a$ was calculated using the following formula:

$$
Y a=\frac{\text { weight of cheese } \times 100}{\text { weight of milk }} .
$$

The moisture-adjusted cheese yield ( $Y m a$ ) was calculated using the formula

$$
Y m a=Y a \times\left(\frac{100-M a}{100-M r}\right),
$$

where $M a$ corresponds to the moisture observed in the cheese samples and $M r$ to the reference moisture 
(Guinee et al., 2006). The $M r$ used (40\%) was obtained from the analysis of 12 different commercial Chihuahua cheese brands.

\section{Texture Analysis}

Texture profile analysis of miniature cheeses was performed $10 \mathrm{~d}$ after their manufacture using a texture analyzer (TA.XTplus; Stable Micro Systems Ltd., London, UK), with a cell load of $50 \mathrm{~kg}$ and a cylinder flat-ended probe $(\mathrm{P} / 2 \mathrm{SL})$ of $2.5-\mathrm{cm}$ diameter. Three cylindrical sections (1.2-cm diameter and $1.5-\mathrm{cm}$ height) from each miniature cheese were compressed $(75 \%$ of their original height) twice using a crosshead speed of $0.05 \mathrm{~cm} / \mathrm{s}$. The second compression was delayed $5 \mathrm{~s}$ from the first compression. Cheese samples were allowed to equilibrate for $1 \mathrm{~h}$ at room temperature $\left(25^{\circ} \mathrm{C}\right)$ before testing. Hardness, fracturability, adhesiveness, springiness, cohesiveness, and apparent Young's modulus were calculated according to Bourne $(1978,2002)$ using the instrument's software (Texture Exponent; Stable Micro Systems Ltd.).

\section{Sensory Analysis}

Chihuahua cheeses (2-kg blocks) were manufactured in a local dairy pilot plant using the conventional procedure but adding PL- $\mathrm{A}_{1}$ or EPS-producing culture, or both, as done with the miniature cheeses. Twenty-five liters of pasteurized milk $\left(63^{\circ} \mathrm{C}\right.$ for $\left.30 \mathrm{~min}\right)$ with $3 \%$ fat was inoculated with freeze-dried starter culture (MM101-LY025; Danisco Deutschland GmbH). Depending on the treatment, cheese milk was inoculated with $1 \%$ (vol/vol) milk previously fermented with the EPS culture (Y 470E; Sacco International) and (or) PL-A 1 (YieldMAX; Chr. Hansen A/S) at 15 LEU per $100 \mathrm{~g}$ of milk. The milk was incubated for $1 \mathrm{~h}$ at $32^{\circ} \mathrm{C}$; then, a solution of $4.6 \mathrm{M} \mathrm{CaCl}_{2}$ was added (to obtain a final concentration in the milk of $1.84 \mathrm{mM}$ ) and chy$\operatorname{mosin}(5.5 \mathrm{~mL} / 100 \mathrm{~L}$; CHY-MAX; Chr. Hansen A/S) was added. After $1 \mathrm{~h}$, the curd was cut with harps into cubes of $0.8 \mathrm{~cm}^{3}$, held for $10 \mathrm{~min}$, and then stirred manually for $1 \mathrm{~h}$. The curd was warmed up to $38^{\circ} \mathrm{C}$ (increasing $1^{\circ} \mathrm{C}$ every $5 \mathrm{~min}$ ) and kept at this temperature for $30 \mathrm{~min}$. After this period of time, whey was drained, and curds were salted $(1 \% \mathrm{NaCl}$, wt/wt) when curds reached a $\mathrm{pH}$ of 5.6. Finally, the curd was placed in rectangular molds of $2 \mathrm{~kg}$ and pressed at $150 \mathrm{kPa}$ overnight using a pneumatic press $(150 \mathrm{kPa})$. Cheeses were stored unpacked in refrigeration $\left(4^{\circ} \mathrm{C}\right)$ at $75 \%$ relative humidity for $48 \mathrm{~h}$ and then packed using polyethylene bags and stored at $3^{\circ} \mathrm{C}$ for $1 \mathrm{wk}$ before being used for sensory analyses. All experimental cheeses were manufactured the same day.

Cheese blocks (10 d old) were cut into small cubes of $1 \mathrm{~cm}^{3}$ and stored at $10^{\circ} \mathrm{C}$ until sensory tests were conducted. Cheese samples were evaluated by staff and students of the University Autonomous of Chihuahua using a ranking test (Meilgaard et al., 1999). Sensory tests were carried out by 50 panelists $(25$ males and 25 females) with an age range of 18 to 39 years old (mean $=24$; median $=21)$. Each trial included 4 cubes of cheese (corresponding to the 4 treatments) identified with a 3-digit code and presented randomly. Panelists were instructed to taste the cheeses and rank them in order of increasing preference in flavor and texture.

\section{Electron Scanning Microscopy}

Preparation of cheese samples was performed according to the procedure described by Dykstra (Dykstra, 1993). Samples from miniature cheeses were finely sliced (1-mm thick) and submerged immediately in a solution with $(2.5 \%, \mathrm{wt} / \mathrm{vol})$ glutaraldehyde and sodium cacodylate $(0.1 \mathrm{M})$. Samples were held for $8 \mathrm{~h}$ at $10^{\circ} \mathrm{C}$ to allow glutaraldehyde fixation. Afterward, cheese samples were dehydrated in increasing concentrations of ethanol $(55,65,95$, and $100 \%)$, washing the cheese samples for $20 \mathrm{~min}$ with each ethanol solution. Finally, samples were dried with $\mathrm{CO}_{2}$ (critical point drying) and coated with a thin layer of $\mathrm{Au}: \mathrm{Pb}$ (60:40). The cheese samples were observed with a scanning microscope (JSM-5800LV; Jeol Ltd., Tokyo, Japan) using an acceleration voltage of $10 \mathrm{kV}$.

\section{Statistical Analysis}

Comparison of polysaccharide production by the EPS-producing culture with and without the presence of PL- $\mathrm{A}_{1}$ was performed using a Student's $t$-test (2-tailed) with a significance level of 0.05 . Cheeses were manufactured 4 times with each treatment in different batches and each batch was manufactured on different days. Data collected from the compositional analysis, texture analysis, and cheese yields were analyzed in a 2-level factorial design with the software Minitab 16 (Minitab Inc., State College, PA). Two (categorical) factors were included in this design: the PL- $\mathrm{A}_{1}$ and the EPS-producing culture. Both factors were applied in 2 levels: presence $(+)$ and absence $(-)$. Data collected from the sensorial analyses were first analyzed using a Friedman analysis (Meilgaard et al., 1999) and then subjected to a multiple comparison test according to the procedure described by Christensen et al. (2006).

\section{RESULTS AND DISCUSSION}

\section{Microbial Growth and EPS Production}

Phospholipids are present in all biological membranes, including the microbial cell membranes (Mus- 
tranta et al., 1995). The hydrolysis of phospholipids by phospholipases generates tensoactive products. The release of these products from the cellular membrane can alter the supramolecular structure (Bourlieu et al., 2012). In this regard, some phospholipases have shown the ability to kill a broad spectrum of gram-positive bacteria (Qu and Lehrer, 1998). For this reason, one concern in this study was the possible effect of PL- $\mathrm{A}_{1}$ against the growth of the EPS-producing bacteria or polysaccharide production. However, the presence of PL- $\mathrm{A}_{1}$ in the media did not affect the growth of the EPS-producing culture (Table 1) or the growth of the starter culture used in the manufacture of cheese (data not shown). The presence of this enzyme did not produce any change on the lag time or growth rate of the EPS-producing culture (Table 1).

The production of polysaccharides by the EPSproducing bacteria was not affected by the addition of PL- $\mathrm{A}_{1}$ in the media (Table 1), obtaining the same polysaccharide yield with or without the addition of PL-A $(\approx 200 \mathrm{mg} / \mathrm{L})$. It has been reported that the yield of EPS produced by LAB varies depending on the strain, medium, and growing conditions from 150 to $600 \mathrm{mg} / \mathrm{L}$ (Degeest et al., 2001).

\section{Compositional Analysis and Cheese Yield}

Addition of PL- $\mathrm{A}_{1}$ into the cheese milk for the manufacture of Chihuahua cheese significantly increased protein retention (in $\mathrm{DM}$ ). Nevertheless, the cheeses manufactured with PL- $\mathrm{A}_{1}$ did not increase the retention of solids or fat in DM (Table 2). Incorporation of EPSproducing bacteria in the manufacture of Chihuahua cheese increased the water activity, protein content (in $\mathrm{DM}$ ), and moisture content. Additionally, the manufac- ture of cheese with EPS-producing culture significantly decreased fat loss in whey and increased fat retention (in DM) in the cheese. Cheeses manufactured with both PL-A $A_{1}$ and EPS-producing cultures had higher water activity, protein content (in DM), and moisture content than control cheeses, but lower $\mathrm{pH}$ and released whey compared with control cheeses. Despite these differences from the control cheeses, it is worth highlighting that no significant differences existed in the $\mathrm{pH}$ and whey released among all the cheese treatments (PL- $\mathrm{A}_{1}$, EPS, and EPS + PL-A $A_{1}$.

Phosphorous and calcium are the most abundant components of salts in milk. Part of these salts is attached to casein micelles as colloidal calcium phosphate (CCP). The pH of the curd when whey is drained and at the moment of pressing determines how much CCP will not be incorporated in the cheese, because acidification leads to dissolution of CCP. Furthermore, the $\mathrm{pH}$ of the curd also may affect the retention of $\mathrm{NaCl}$ added in the manufacture of cheese. Cheeses with low $\mathrm{pH}$ lose more salt in the expressed whey than cheeses with high $\mathrm{pH}$ (Walstra et al., 2006). In the current work, it was observed that the mineral content of cheeses (including the $\mathrm{NaCl}$ added) decreased markedly in those manufactured with EPS-producing bacteria (alone or in combination with PL-A $\mathrm{A}_{1}$ ). The reduction of mineral content in the cheeses manufactured with EPSproducing bacteria was not attributed to $\mathrm{pH}$ variations, because all the cheese treatments had similar $\mathrm{pH}$ in the curds during their manufacture (data not shown) and $10 \mathrm{~d}$ after manufacture (Table 2). For this reason, the reduction in mineral content in the cheeses manufactured with EPS-producing bacteria was attributed to changes in the water retention of these cheeses (Table 2 ) rather than to differences in $\mathrm{pH}$. On the other hand,

Table 1. Influence of phospholipase $\mathrm{A}_{1}$ on exopolysaccharide production and growth of Streptococcus thermophilus ${ }^{1}$

\begin{tabular}{|c|c|c|}
\hline \multirow[b]{2}{*}{ Item } & \multicolumn{2}{|c|}{ Treatment $^{2}$} \\
\hline & $\begin{array}{l}\text { M17 broth } \\
\text { (control) }\end{array}$ & $\begin{array}{l}\text { M17 broth with added } \\
\text { phospholipase } A_{1}\end{array}$ \\
\hline $\begin{array}{l}\text { Growth rate }^{3} \\
\text { Lag time }{ }^{3}(\mathrm{~h}) \\
\mathrm{SE} \\
\mathrm{R}^{2} \\
\text { Glucose equivalents }(\mathrm{mg} / \mathrm{L}) ; t=0^{4} \\
\text { Glucose equivalents }(\mathrm{mg} / \mathrm{L}) ; t=24 \\
\text { Polysaccharide yield }(\mathrm{mg} / \mathrm{L})\end{array}$ & $\begin{array}{l}0.110 \\
\text { Not observed } \\
0.029 \\
0.92 \\
163.70 \pm 0.21^{\mathrm{a}} \\
371.88 \pm 5.83^{\mathrm{a}} \\
208.18 \pm 3.28^{\mathrm{a}}\end{array}$ & $\begin{array}{l}0.129 \\
\text { Not observed } \\
0.035 \\
0.94 \\
156.90 \pm 1.30^{\mathrm{b}} \\
363.44 \pm 1.59^{\mathrm{a}} \\
206.54 \pm 1.43^{\mathrm{a}}\end{array}$ \\
\hline \multicolumn{3}{|c|}{$\begin{array}{l}\text { a,b Means within a row with different superscript letters differ }(P<0.05) ; \mathrm{n}=4 . \\
{ }^{1} \text { Results are presented as means } \pm \mathrm{SD} \text {. } \\
{ }^{2} \text { Treatment with phospholipase } \mathrm{A}_{1} \text { included addition of } 15 \text { Lecitase units } / 100 \mathrm{~g} \text { of M17 broth. } \\
{ }^{3} \text { Growth parameters were obtained by fitting } 3 \text { repetitions of each treatment to the Baranyi and Roberts }(1994) \\
\text { equation. } \\
{ }^{4} t=\text { incubation time in hours. }\end{array}$} \\
\hline
\end{tabular}


Table 2. Effect of adding phospholipase $\mathrm{A}_{1}\left(\mathrm{PL}-\mathrm{A}_{1}\right)$ or exopolysaccharide (EPS)-producing bacteria, or both, to cheese milk on the chemical composition of miniature Chihuahua cheeses $10 \mathrm{~d}$ after their manufacture

\begin{tabular}{|c|c|c|c|c|c|}
\hline \multirow[b]{2}{*}{ Item $^{1}$} & \multicolumn{4}{|c|}{ Treatment $^{2}$} & \multirow[b]{2}{*}{ SEM } \\
\hline & $\begin{array}{l}\text { Control } \\
(\mathrm{n}=4)\end{array}$ & $\begin{array}{l}\text { PL-A } \\
(\mathrm{n}=4)\end{array}$ & $\begin{array}{c}\text { EPS } \\
(\mathrm{n}=4)\end{array}$ & $\begin{array}{c}\mathrm{EPS}+\mathrm{PL}-\mathrm{A}_{1} \\
\quad(\mathrm{n}=4)\end{array}$ & \\
\hline \multicolumn{6}{|l|}{ Cheese } \\
\hline Cheese weight $(\mathrm{g})$ & $20.61^{\mathrm{c}}$ & $25.50^{\mathrm{b}}$ & $26.25^{\mathrm{a}}$ & $25.82^{\mathrm{ab}}$ & 0.242 \\
\hline $\mathrm{pH}$ & $5.44^{\mathrm{b}}$ & $5.32^{\mathrm{ab}}$ & $5.34^{\mathrm{ab}}$ & $5.20^{\mathrm{a}}$ & 0.042 \\
\hline$a_{w}$ & $0.970^{\mathrm{a}}$ & $0.972^{\mathrm{ab}}$ & $0.978^{\mathrm{b}}$ & $0.975^{\mathrm{ab}}$ & 0.002 \\
\hline Moisture (g/100 g) & $43.09^{\mathrm{a}}$ & $43.42^{\mathrm{ab}}$ & $48.28^{\mathrm{c}}$ & $45.72^{\mathrm{bc}}$ & 0.614 \\
\hline Fat $(\mathrm{g} / 100 \mathrm{~g})$ & $30.56^{\mathrm{ab}}$ & $29.43^{\mathrm{a}}$ & $30.45^{\mathrm{ab}}$ & $31.32^{\mathrm{b}}$ & 0.296 \\
\hline Protein (g/100 g) & $21.87^{\mathrm{a}}$ & $25.67^{\mathrm{b}}$ & $22.84^{\mathrm{a}}$ & $23.62^{\mathrm{ab}}$ & 0.589 \\
\hline Ash $(\mathrm{g} / 100 \mathrm{~g})$ & $3.04^{\mathrm{ab}}$ & $3.19^{\mathrm{a}}$ & $2.71^{\mathrm{c}}$ & $2.73^{\mathrm{bc}}$ & 0.081 \\
\hline TS $(\mathrm{g} / 100 \mathrm{~g})$ & $56.91^{\mathrm{a}}$ & $56.58^{\mathrm{ab}}$ & $51.72^{\mathrm{c}}$ & $54.28^{\mathrm{bc}}$ & 0.614 \\
\hline $\operatorname{FDM}(\%)$ & $53.79^{\mathrm{b}}$ & $52.03^{\mathrm{b}}$ & $58.90^{\mathrm{a}}$ & $57.71^{\mathrm{a}}$ & 0.832 \\
\hline $\operatorname{PDM}(\%)$ & $38.47^{\mathrm{b}}$ & $45.39^{\mathrm{a}}$ & $44.17^{\mathrm{a}}$ & $43.50^{\mathrm{a}}$ & 1.102 \\
\hline \multicolumn{6}{|l|}{ Whey } \\
\hline Weight of bulk whey $(\mathrm{g})$ & $217.36^{\mathrm{a}}$ & $212.66^{\mathrm{b}}$ & $211.76^{\mathrm{b}}$ & $213.26^{\mathrm{b}}$ & 0.560 \\
\hline Ionic calcium $\left(\mathrm{m} M \times 10^{-3}\right)$ & $26.63^{\mathrm{a}}$ & $17.87^{\mathrm{b}}$ & $25.55^{\mathrm{a}}$ & $14.84^{\mathrm{b}}$ & 2.472 \\
\hline Fat $(\mathrm{g} / 100 \mathrm{~g})$ & $0.350^{\mathrm{a}}$ & $0.192^{\mathrm{ab}}$ & $0.097^{\mathrm{b}}$ & $0.227^{\mathrm{ab}}$ & 0.056 \\
\hline Fat lost in whey (FL\%) & $10.89^{\mathrm{a}}$ & $5.23^{\mathrm{ab}}$ & $2.75^{\mathrm{b}}$ & $3.40^{\mathrm{ab}}$ & 1.86 \\
\hline
\end{tabular}

${ }^{\mathrm{a}-\mathrm{c}}$ Means within a row with different superscript letters differ $(P<0.05)$.

${ }^{1} \mathrm{a}_{\mathrm{w}}=$ water activity; $\mathrm{FDM}=$ fat in DM; PDM = protein in DM.

${ }^{2}$ Control $=$ cheese milk without EPS-producing culture or PL- $\mathrm{A}_{1} ;$ PL- $\mathrm{A}_{1}=$ cheese milk with added PL- $\mathrm{A}_{1}(15$ Lecitase units $/ 100 \mathrm{~g}$ of milk); EPS = cheese milk inoculated at $1 \%$ (vol/vol) with an EPS-producing culture; $\mathrm{EPS}+\mathrm{PL}-\mathrm{A}_{1}=$ cheese milk with an added EPS-producing culture and PL- $\mathrm{A}_{1}$.

the whey obtained from the cheeses manufactures with PL- $\mathrm{A}_{1}$ (alone or in combination) presented the lowest concentration of ionic calcium. This suggests that ionic calcium was retained in the cheese matrix. Nevertheless, it is still not clear how the PL- $\mathrm{A}_{1}$ promotes the retention of ionic calcium.

Cheeses manufactured with PL- $\mathrm{A}_{1}$ and the cheeses made with EPS-producing bacteria, as well as those manufactured with both PL-A $\mathrm{A}_{1}$ and EPS-producing bacteria showed an increase in their final weight and a significant reduction in the amount of whey released during their manufacture, compared with control cheeses (Table 2). These changes in the weight of the cheeses and the release of whey affected the yields of these cheese processes. The yield of control cheese was $9.21 \%$, and the incorporation of EPS-producing bacteria in the manufacture of Chihuahua cheese significantly increased the yield to $10.53 \%$ (Figure 1). The addition of PL- $\mathrm{A}_{1}$ into the cheese-milk did not cause a significant increase in cheese yield $(9.66 \%)$ compared with control cheese. In contrast, the combination of PL- $\mathrm{A}_{1}$ and EPS-producing bacteria in the manufacture of Chihuahua cheese produced the highest actual yield (10.81\%). The moisture-adjusted cheese yield ( Yma) of cheeses manufactured with PL- $\mathrm{A}_{1}$ was $9.39 \%$, whereas cheeses made with EPS-producing bacteria obtained a Yma of $9.07 \%$. These yields were not significantly higher $(P>0.05)$ than the Yma observed in control cheeses $(8.73 \%)$. Cheeses manufactured with both PL-
$\mathrm{A}_{1}$ and EPS-producing bacteria significantly increased their Yma (9.78\%) compared with control cheeses. The $Y m a$ was calculated to eliminate the direct effect of differences in cheese moisture. The cheeses manufactured with PL- $\mathrm{A}_{1}$ or with EPS-producing bacteria did not significantly increase the Yma compared with control cheeses because these treatments mainly improved the water retention. In contrast, the cheeses manufactured with both PL-A1 and EPS-producing culture increased the Yma by improving the retention of water, fat, and protein in the cheese.

The idea of using phospholipases to increase cheese yield had not been considered until recently, and the effect of these enzymes on the MFGM remains unclear (De Maria et al., 2007). Bovine milk typically contains $>10^{10}$ fat globules per milliliter and about $60 \%$ of phospholipids occur in the MFGM (Keenan and Mather, 2006; Walstra et al., 2006). Some authors have reported that phospholipase radically changes the surface of the MFGM, detaching bilayer fragments (lysophospholipids and FA) in the aqueous phase (Lilbæk et al., 2007; Bourlieu et al., 2012). Modification of the surface of the MFGM also reduces the $\zeta$-potential on the surface of fat globules due to intensification of negative charges from carboxylate anions (Bourlieu et al., 2012). The change in the $\zeta$-potential avoids the coalescence of fat globules, as was observed by Bourlieu et al. (2012) and Lilbæk et al. (2007), because the aggregation of milk globules occurs only if the van der Waals attraction and repulsive 
steric forces are larger than the electrostatic repulsion. Nevertheless, the increase in negative charges at the surface of the MFGM also improves the solubility of fat globules in the serum phase and might promote their loss during whey drainage. This may explain the poor retention of fat in the Chihuahua cheeses manufactured with PL- $\mathrm{A}_{1}$. In contradiction with this finding, it has been reported that the use of PL- $\mathrm{A}_{1}$ (from Fusarium venenatum) in the manufacture of Mozzarella cheese increases fat retention, moisture content, and cheese yield by $3.2 \%$ (Lilbæk et al., 2006). This discrepancy may be due to differences in the manufacture procedures between Mozzarella and Chihuahua cheese. In the manufacture of Mozzarella cheese, the curd is stretched and kneaded in hot water. During the plasticizing of the curd, some fat is lost in the hot water and probably the effect of PL- $\mathrm{A}_{1}$ on fat retention becomes more evident.

On the other hand, protein content increased in Chihuahua cheeses manufactured with PL- $\mathrm{A}_{1}$ (alone or in combination with the EPS-producing bacteria). Some authors have suggested that lysophospholipids and FA derived from PL-A $\mathrm{A}_{1}$ action interact with milk proteins, including whey proteins and caseins. Binding of lysophospholipids to milk proteins prevents proteinprotein interactions and modifies their surface properties (Lilbæk et al., 2007). Therefore, the formation of lysophospholipid-protein complexes might improve the retention of some additional proteins in the cheese matrix.

The use of an EPS-producing culture enhanced the moisture content and cheese yield of Chihuahua cheese. Several authors have reported the improvement of water retention and cheese yield by the use of EPS-producing bacteria. In low-fat Cheddar cheese, an increase in water retention from 1.24 to $4.80 \%$ and an improvement of the cheese yield of 0.58 to $0.60 \%$ has been observed (Dabour et al., 2006; Costa et al., 2010, 2012). Previous research on Mozzarella cheese has reported a $6.1 \%$ increase in the moisture content (Petersen et al., 2000) and research conducted on fresh cheese showed the ability of EPS-producing bacteria to increase yield by $2.21 \%$, the moisture by $3.90 \%$, and fat content by 7.64\% (Jiménez-Guzmán et al., 2009). In general, it has been observed that the use of an EPS-producing culture in the manufacture of cheese increases yield mainly through higher water retention. Such results may vary, depending on the cheese variety and the nature of the EPS produced by the LAB. Some authors have suggested that EPS filaments are attached to the protein matrix (by electrostatic interactions), creating a web of filaments (Ayala-Hernandez et al., 2008). The additional water retained in the cheese matrix is weakly bound to the EPS filaments and is just mechanically trapped in the web of filaments (Laws and Marshall,

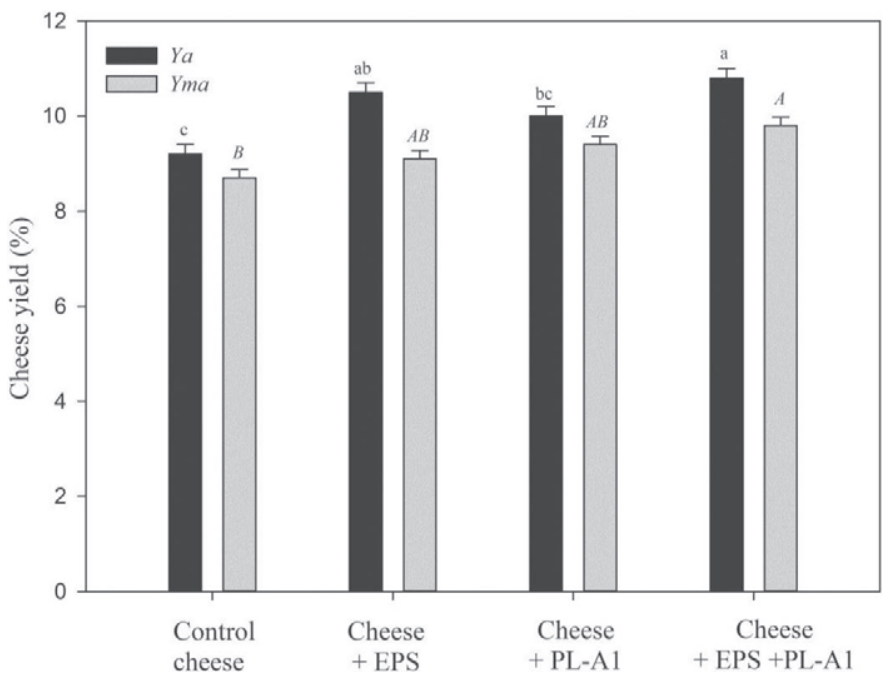

Figure 1. Actual cheese yield $(Y a)$ and moisture-adjusted cheese yield (Yma) of Chihuahua cheese manufactured with an exopolysaccharide (EPS)-producing bacteria or phospholipase $\mathrm{A}_{1}\left(\mathrm{PL}-\mathrm{A}_{1}\right)$, or both. Bars of the same color with different letters ( $\mathrm{a}-\mathrm{c}$, or $A$ and $B$ ) are significantly different (multiple mean comparison, Tukey-Kramer test, $\alpha=0.05)$.

2001; Ayala-Hernandez et al., 2008; Costa et al., 2010). This may explain the significant increase in the water activity of the Chihuahua cheeses manufactured with an EPS-producing culture.

In the present study, the mini-cheeses manufactured with PL- $\mathrm{A}_{1}$ in combination with EPS-producing bacteria had the highest $Y m a$ and the smallest loss of ionic calcium into the whey. Interestingly, the micrographs (Figure 2) from these cheeses did not show a web of filamentous polysaccharides attached to the cheese matrix, as was observed in those cheeses manufactured only with the EPS-producing bacteria. The interaction of bacterial EPS with the casein matrix has been widely recognized, but little attention has been paid to the relation of EPS with the lipid fraction or other molecules. Results from this study suggest that some EPS bind to components of the MFGM and that modification of the MFGM by action of the PL- $\mathrm{A}_{1}$ might alter these interactions. However, more research is required to understand more fully the interaction of polysaccharides with the components of the MFGM surface.

\section{Texture Analysis}

Texture profile analysis showed that control cheese was significantly harder than cheeses manufactured with a PL-A $\mathrm{A}_{1}$ or EPS-producing bacteria, or both (Table 3). Incorporation of an EPS-producing culture or PL-A $\mathrm{A}_{1}$, or both, in the manufacture of Chihuahua cheese also reduced the force required to fracture the cheese samples (fracturability), producing crumblier 

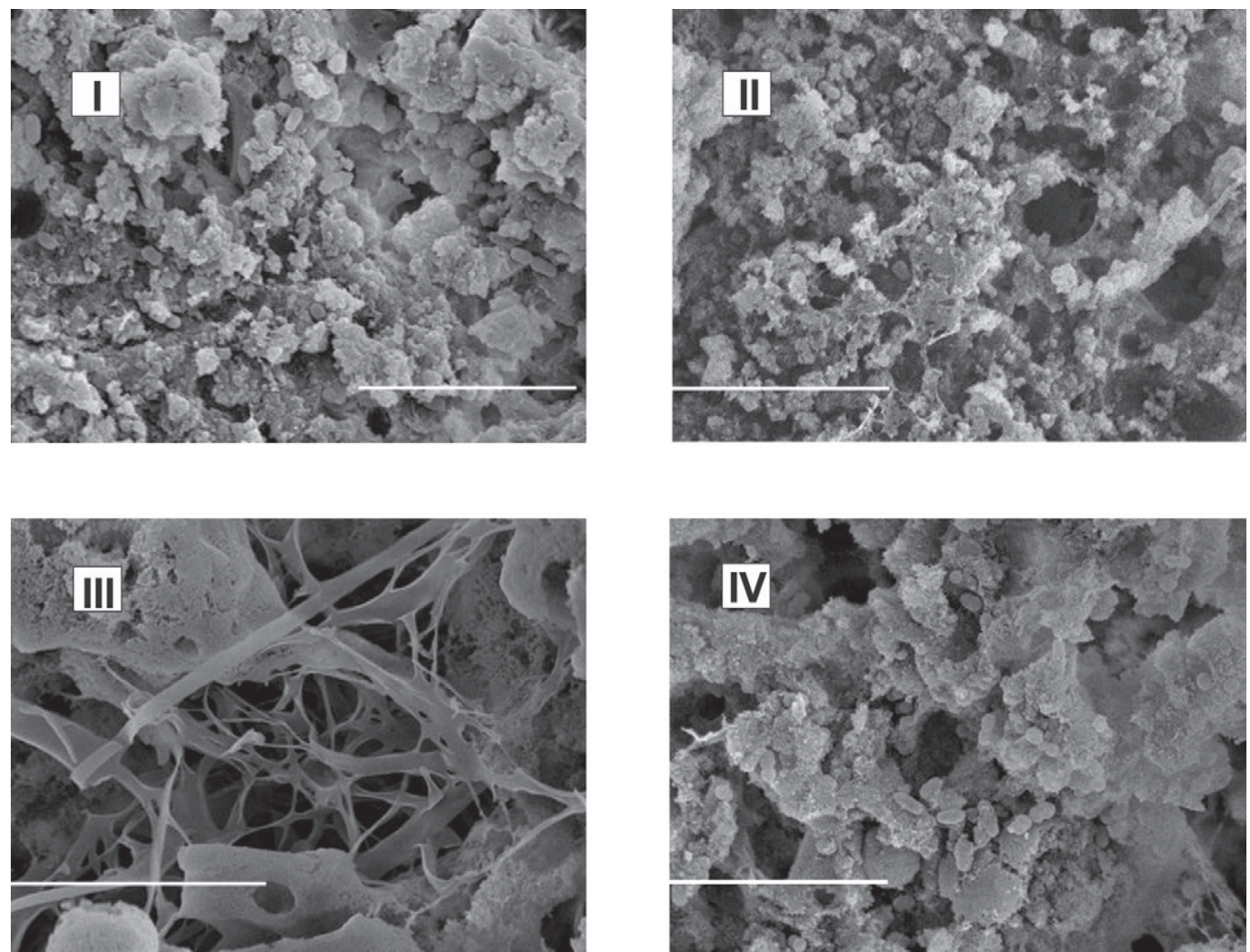

Figure 2. Scanning electron microscopy of Chihuahua cheeses. I = control Chihuahua cheese without phospholipase or exopolysaccharideproducing bacteria; II = Chihuahua cheese with phospholipase $\mathrm{A}_{1}$; III = Chihuahua cheese made with exopolysaccharide-producing bacteria; $\mathrm{IV}=$ Chihuahua cheese made with phospholipase $\mathrm{A}_{1}$ and exopolysaccharide-producing bacteria. The white line represents a length of $10 \mu \mathrm{m}$.

cheeses. Similarly, Dabour et al. (2006) reported a decrement of hardness in low-fat Cheddar cheese manufactured with ropy EPS streptococci. The decrement in hardness of Chihuahua cheese by addition of PL- $\mathrm{A}_{1}$ or EPS-producing bacteria, or both, is probably related to changes in the components of the cheese; chiefly to enhanced moisture content in cheese manufactured with EPS-producing bacteria and the protein-to-fat ratio in cheese with PL- $\mathrm{A}_{1}$. Nevertheless, other factors such as the $\mathrm{pH}$ and ash content might have affected the cheese texture. Cheeses with a less acidic $\mathrm{pH}$ and high ash content (such as the control cheese) were harder than cheeses with a more acidic $\mathrm{pH}$ and low ash content (see Table 2). The solubilization of colloidal calcium increases at $\mathrm{pH} 5$, decreasing the interactions between proteins and improving the solvation of caseins and hydration of the protein matrix (Lucey et al., 2003). It has been reported that reducing the $\mathrm{pH}$ of Cheddar cheese from 5.4 to 5.0 increases the calcium solubilization and moisture content, producing a decrease in the hardness of the cheese (Pastorino et al., 2003).

Springiness and cohesiveness of Chihuahua cheese were not significantly modified by the addition of the
PL- $\mathrm{A}_{1}$ or the EPS-producing bacteria, or both. However, the chewiness (energy required to masticate a solid food product) of Chihuahua cheeses was significantly reduced when PL- $\mathrm{A}_{1}$ was incorporated in the process, possibly caused by changes in the proportion of protein and fat in the cheeses manufactured with PL- $\mathrm{A}_{1}$ (Table 2 ). These changes in chewiness were expected, as this parameter is related to hardness, springiness, and cohesiveness of the cheeses (Bourne, 2002). The cohesiveness and springiness did not change significantly in any of the cheese treatments and thus chewiness became approximately proportional to the hardness of the cheeses.

The apparent Young's modulus represents the stiffness of the material to an applied load. A Young's modulus with larger value denotes that higher stress (force per unit area) is needed to generate a given strain (deformation). Cheese manufactured with PL- $\mathrm{A}_{1}$ obtained the lowest Young's modulus value, whereas cheese manufactured with EPS obtained the highest Young's modulus value. The enhancement of the stiffness in the cheese manufactured with the EPS-producing bacteria may be explained by the increase in water content and the formation of a filamentous web of polysaccharides 
Table 3. Effects of adding phospholipase $\mathrm{A}_{1}\left(\mathrm{PL}-\mathrm{A}_{1}\right)$ or exopolysaccharide (EPS)-producing bacteria, or both, in cheese milk on the texture properties of miniature Chihuahua cheeses $10 \mathrm{~d}$ after their manufacture

\begin{tabular}{|c|c|c|c|c|c|}
\hline \multirow[b]{2}{*}{ Item } & \multicolumn{4}{|c|}{ Treatment $^{1}$} & \multirow[b]{2}{*}{ SEM } \\
\hline & $\begin{array}{l}\text { Control } \\
(\mathrm{n}=4)\end{array}$ & $\begin{array}{l}\text { PL-A } \\
(\mathrm{n}=4)\end{array}$ & $\begin{array}{c}\text { EPS } \\
(\mathrm{n}=4)\end{array}$ & $\begin{array}{c}\mathrm{EPS}+\mathrm{PL}-\mathrm{A}_{1} \\
\quad(\mathrm{n}=4)\end{array}$ & \\
\hline Hardness $(\mathrm{N})$ & $5.81^{\mathrm{b}}$ & $4.07^{\mathrm{a}}$ & $4.10^{\mathrm{a}}$ & $3.83^{\mathrm{a}}$ & 0.331 \\
\hline Fracturability (N) & $4.38^{\mathrm{b}}$ & $2.08^{\mathrm{a}}$ & $2.71^{\mathrm{a}}$ & $2.12^{\mathrm{a}}$ & 0.339 \\
\hline Springiness (mm) & $4.55^{\mathrm{a}}$ & $3.64^{\mathrm{a}}$ & $3.99^{\mathrm{a}}$ & $2.89^{\mathrm{a}}$ & 0.463 \\
\hline Chewiness $(\mathrm{mJ})$ & $5.79^{\mathrm{a}}$ & $2.06^{\mathrm{b}}$ & $3.77^{\mathrm{ab}}$ & $1.74^{\mathrm{b}}$ & 0.771 \\
\hline Cohesiveness & $0.222^{\mathrm{a}}$ & $0.205^{\mathrm{a}}$ & $0.207^{\mathrm{a}}$ & $0.171^{\mathrm{a}}$ & 0.026 \\
\hline Apparent Young's modulus (kPa) & $5.2^{\mathrm{b}}$ & $4.7^{\mathrm{c}}$ & $5.9^{\mathrm{a}}$ & $4.4^{\mathrm{c}}$ & 0.280 \\
\hline
\end{tabular}

in the cheese matrix. The filamentous polysaccharides produced by EPS-producing bacteria were observed intertwined in the protein matrix of the cheese (Figure 2), producing larger whey pockets than those observed in control cheeses or cheeses manufactures with PL- $\mathrm{A}_{1}$. Other authors have observed similar characteristics in the matrix of cheeses manufactured with EPS-producing bacteria (Dabour et al., 2006; Ayala-Hernandez et al., 2008). The structure observed in the cheeses manufactured with the EPS-producing culture explains the increase in water content, but also provides more evidence supporting the idea that water is just trapped and probably weakly bound.

\section{Sensory Analysis}

Commercial Chihuahua cheese usually displays mild to tangy flavor and has a firm but yet not hard texture. This cheese is slightly sticky in the mouth and quite soft when chewed (Van Hekken et al., 2006). All the participants in the sensory evaluation expressed to be regular consumers of Chihuahua cheese. All cheeses were equally preferred in flavor, with the exception of the cheese manufactured with both PL- $\mathrm{A}_{1}$ and EPSproducing bacteria, which had highest preference in flavor (Table 4). One concern in the case of cheeses manufactured with phospholipase was the possible development of rancid flavors produced by hydrolysis of triglycerides. Nevertheless, and according to the comments of the judges, these cheeses did not showed rancid flavor. On the other hand, the texture of the cheese manufactured with EPS-producing bacteria was perceived as unpleasant by most of the judges. This may have been caused by the excessive increase in water retention and modification of rheological properties (Table 3). Similarly, Dabour et al. (2006) reported that the use of ropy EPS streptococci induced the formation of a less compact texture, which is undesirable in aged Cheddar cheese, usually characterized by harder texture.

\section{CONCLUSIONS}

The presence of PL- $A_{1}$ in the growth medium did not affect the growth and polysaccharide production by the EPS-producing bacteria. The use of PL- $\mathrm{A}_{1}$ in the manufacture of Chihuahua cheese did not increase fat retention or cheese yield as was expected. The use of EPS improved cheese yield by increasing water and fat retention, but caused a negative effect on the texture and flavor of Chihuahua cheese. The combination of PL- $\mathrm{A}_{1}$ with the EPS-producing culture improved cheese yield and increased the moisture and fat content. The cheeses with the best flavor and texture were those manufactured with PL- $\mathrm{A}_{1}$ and the cheeses manufactured with the combination of PL- $\mathrm{A}_{1}$ and EPS-producing culture. On the other hand, it is still unclear how PL- $\mathrm{A}_{1}$ produces modifications in the milk fat, particularly on the MFGM and the effect of these changes on the quality of the cheese. Another

Table 4. Sensory analysis of Chihuahua cheese manufactured with an exopolysaccharide (EPS)-producing bacteria or phospholipase $\mathrm{A}_{1}$ $\left(\mathrm{PL}-\mathrm{A}_{1}\right)$, or both $^{1}$

\begin{tabular}{lcc}
\hline & \multicolumn{2}{c}{ Rank sum $^{2}$} \\
\cline { 2 - 3 } Treatment & Flavor & Texture \\
\hline Control cheese & $98^{\mathrm{a}}$ & $110^{\mathrm{ab}}$ \\
Cheese made with PL-A 1 & $134^{\mathrm{ab}}$ & $140^{\mathrm{b}}$ \\
Cheese made with EPS-producing culture & $103^{\mathrm{a}}$ & $95^{\mathrm{a}}$ \\
Cheese made with EPS + PL-A & $156^{\mathrm{b}}$ & $145^{\mathrm{b}}$ \\
\hline
\end{tabular}

$\overline{\mathrm{a}, \mathrm{b}}$ Rank sums within a column with different superscript letters differ, according to the critical difference value between samples (Christensen et al., 2006).

${ }^{1}$ The significance level was $P=0.01$ and the critical difference was 39 for both flavor and texture.

${ }^{2}$ Rank sum obtained from the responses of 50 nontrained judges. 
issue derived from this study that would be important to address would be the residual phospholipase activity and its effect during the ripening of cheese. More study is also required regarding the interaction of bacterial polysaccharides with cheese components, such as the surface of the MFGM. Despite the lack of a better understanding of the intimate mechanisms involved, clear evidence exists that cheese yield is increased when PL- $\mathrm{A}_{1}$ and EPS-producing culture are used in combination in the manufacture of cheese. These findings need still to be successfully extrapolated and proven in large-scale production. Additionally, more research is required to understand the interactions established by PL- $\mathrm{A}_{1}$ and the bacterial polysaccharides with the cheese components.

\section{REFERENCES}

Abd El-Gawad, M. A. M., and N. S. Ahmed. 2011. Cheese yield as affected by some parameters. ACTA Scientiarum Polonorum Technologia Alimentaria 10:131-153.

AOAC International. 1998. Official Methods of Analysis. 16th ed. AOAC International, Washington, DC.

Ayala-Hernandez, I., H. D. Goff, and M. Corredig. 2008. Interactions between milk proteins and exopolysaccharides produced by Lactococcus lactis observed by scanning electron microscopy. J. Dairy Sci. 91:2583-2590.

Banks, J. M. 2007. Cheese yield. Pages 100-110 in Cheese Problems Solved. P. L. H. McSweeney, ed. CRC Press, New York, NY.

Baranyi, J., and T. A. Roberts. 1994. A dynamic approach to predicting bacterial growth in food. Int. J. Food Microbiol. 23:277-294.

Barbano, D. M., R. R. Rasmussen, and J. M. Lynch. 1991. Influence of milk somatic cell count and milk age on cheese yield. J. Dairy Sci. 74:369-388.

Bermúdez-Aguirre, D., and G. V. Barbosa-Cánovas. 2010. Processing of soft Hispanic cheese ("Queso Fresco") using thermo-sonicated milk: A study of physicochemical characteristics and storage life. J. Food Sci. 75:S548-S558.

Bourlieu, C., F. Rousseau, V. Briard-Bion, M.-N. Madec, and S. Bouhallab. 2012. Hydrolysis of native milk fat globules by microbial lipases: Mechanisms and modulation of interfacial quality. Food Res. Int. 49:533-544.

Bourne, M. 1978. Texture profile analysis. Food Technol. 32:62-66,72.

Bourne, M. 2002. Food Texture and Viscosity, Concept and Measurement. Academic Press, London, UK.

Christensen, Z. T., L. V. Ogden, M. L. Dunn, and D. L. Eggett. 2006. Multiple comparison procedures for analysis of ranked data. J. Food Sci. 71:S132-S143.

Costa, N. E., D. J. O'Callaghan, J. M. Mateo, V. Chaurin, M. Castillo, J. A. Hannon, P. L. H. McSweeney, and T. P. Beresford. 2012. Influence of an exopolysaccharide produced by a starter on milk coagulation and curd syneresis. Int. Dairy J. 22:48-57.

Costa, N. E., J. A. Hannon, T. P. Guinee, M. A. E. Auty, P. L. McSweeney, and T. P. Beresford. 2010. Effect of exopolysaccharide produced by isogenic strains of Lactococcus lactis on half-fat Cheddar cheese. J. Dairy Sci. 93:3469-3486.

Dabour, N., E. Kheadr, N. Benhamou, I. Fliss, and G. LaPointe. 2006. Improvement of texture and structure of reduced-fat Cheddar cheese by exopolysaccharide-producing lactococci. J. Dairy Sci. 89:95-110.

Degeest, B., F. Vaningelgem, and L. De Vuyst. 2001. Microbial physiology, fermentation kinetics, and process engineering of heteropolysaccharide production by lactic acid bacteria. Int. Dairy J. 11:747-757.
De Maria, L., J. Vind, K. M. Oxenbøll, A. Svendsen, and S. Patkar. 2007. Phospholipases and their industrial applications. Appl. Microbiol. Biotechnol. 74:290-300.

Duboc, P., and B. Mollet. 2001. Applications of exopolysaccharides in the dairy industry. Int. Dairy J. 11:759-768.

DuBois, M., K. A. Gilles, J. K. Hamilton, P. A. Rebers, and F. Smith. 1956. Colorimetric method for determination of sugars and related substances. Anal. Chem. 28:350-356.

Dykstra, M. J. 1993. A Manual of Applied Techniques for Biological Electron Microscopy. Plenum Press, New York, NY.

Fagan, C. C., M. Castillo, F. A. Payne, C. P. O'Donnell, and D. J. O'Callaghan. 2007. Effect of cutting time, temperature, and calcium on curd moisture, whey fat losses, and curd yield by response surface methodology. J. Dairy Sci. 90:4499-4512.

Guinee, T. P., B. T. O'Kennedy, and P. M. Kelly. 2006. Effect of milk protein standardization using different methods on the composition and yields of Cheddar cheese. J. Dairy Sci. 89:468-482.

Guinee, T. P., E. O. Mulholland, J. Kelly, and D. J. O. Callaghan. 2007. Effect of protein-to-fat ratio of milk on the composition, manufacturing efficiency, and yield of Cheddar cheese. J. Dairy Sci. 90:110-123.

Gutiérrez-Méndez, N., and G. V. Nevárez-Moorillon. 2009. Chihuahua cheese: The history of a Mexican cheese. Carnilac Industrial $24: 27-34$.

Hansen, L. D. T. 2005. Las migraciones menonitas al norte de México entre 1922 y 1940. Migraciones Internacionales 3:5-31.

Hynes, E., J.-C. Ogier, and A. Delacroix-Buchet. 2000. Protocol for the manufacture of miniature washed-curd cheese under controlled microbiological conditions. Int. Dairy J. 10:733-737.

Hynes, E., J.-C. Ogier, O. Son, and A. Delacroix-Buchet. 2003. Influence of starter and adjunct lactobacilli culture on ripening of miniature washed-curd cheeses. Lait 83:17-29.

Jiménez-Guzmán, J., A. Flores-Nájera, A. E. Cruz-Guerrero, and M. García-Garibay. 2009. Use of an exopolysaccharide-producing strain of Streptococcus thermophilus in the manufacture of Mexican Panela cheese. Lebensm. Wiss. Technol. 42:1508-1512.

Keenan, T. W., and I. H. Mather. 2006. Intracellular origin of milk fat globules and the nature of the milk fat globule membrane. Pages 137-171 in Advanced Dairy Chemistry. P. F. Fox and P. L. H. McSweeney, ed. Springer, New York, NY.

Laws, A. P., and V. M. Marshall. 2001. The relevance of exopolysaccharides to the rheological properties in milk fermented with ropy strains of lactic acid bacteria. Int. Dairy J. 11:709-721.

Lilbæk, H. M., T. M. Fatum, R. Ipsen, and N. K. Sørensen. 2007. Modification of milk and whey surface properties by enzymatic hydrolysis of milk phospholipids. J. Agric. Food Chem. 55:2970-2978.

Lilbæk, H. M., M. L. Broe, E. Høier, T. M. Fatum, R. Ipsen, and N. K. Sørensen. 2006. Improving the yield of Mozzarella cheese by phospholipase treatment of milk. J. Dairy Sci. 89:4114-4125.

Lin, T. Y., and M.-F. Chang Chien. 2007. Exopolysaccharides production as affected by lactic acid bacteria and fermentation time. Food Chem. 100:1419-1423.

Lucey, J. A., M. E. Johnson, and D. S. Horne. 2003. Perspectives on the basis of the rheology and texture properties of cheese. J. Dairy Sci. $86: 2725-2743$.

Meilgaard, M., G. V. Civille, and B. T. Carr. 1999. Sensory Evaluation Techniques. CRC Press, Boca Raton, FL.

Milesi, M. M., M. Candioti, and E. Hynes. 2007. Mini soft cheese as a simple model for biochemical studies on cheese-making and ripening. Lebensm. Wiss. Technol. 40:1427-1433.

Milesi, M. M., P. L. H. McSweeney, and E. R. Hynes. 2008. Impact of chymosin- and plasmin-mediated primary proteolysis on the growth and biochemical activities of lactobacilli in miniature Cheddar-type cheeses. J. Dairy Sci. 91:3277-3290.

Mustranta, A., P. Forssell, and K. Poutanen. 1995. Comparison of lipases and phospholipases in the hydrolysis of phospholipids. Process Biochem. 30:393-401.

Nielsen, P. M., inventor. 2001. Process for producing cheese. Novozymes A/S and Novozymes North America Inc., assignees. Denmark Patent No. EP1162889B1. 
Nielsen, S. S. 2010. Food Analysis Laboratory Manual. 2nd ed. Springer, New York, NY.

Pastorino, A. J., C. L. Hansen, and D. J. McMahon. 2003. Effect of $\mathrm{pH}$ on the chemical composition and structure-function relationships of Cheddar cheese. J. Dairy Sci. 86:2751-2760.

Patkar, S. P., D. Higgins, T. M. Fatum, J. Vind, and S. A. Madkor, inventors. 2006. Phospholipase variants. Chr. Hansen A/S, Novozymes A/S, and Novozymes North America Inc., assignees. Denmark Patent No. EP1639102A2.

Petersen, B. L., R. I. Dave, D. J. McMahon, C. J. Oberg, and J. R. Broadbent. 2000. Influence of capsular and ropy exopolysaccharide-producing Streptococcus thermophilus on Mozzarella cheese and cheese whey. J. Dairy Sci. 83:1952-1956.

Qu, X.-D., and R. I. Lehrer. 1998. Secretory phospholipase $A_{2}$ is the principal bactericide for staphylococci and other gram-positive bacteria in human tears. Infect. Immun. 66:2791-2797.

Shakeel-Ur-Rehman, A. H. Pripp, P. L. H. McSweeney, and P. F. Fox. 1999. Assessing the proteolytic and cheese ripening properties of single strains of Lactococcus in miniature cheeses. Lait 79:361383.

Shakeel-Ur-Rehman, P. F. Fox, P. L. H. McSweeney, S. A. Madkor, and N. Y. Farkye. 2001. Alternatives to pilot plant experiments in cheese-ripening studies. Int. J. Dairy Technol. 54:121-126.

Shakeel-Ur-Rehman, P. L. H. McSweeney, and P. F. Fox. 1998. Protocol for the manufacture of miniature cheeses. Lait 78:607-620.

Tunick, M. H., D. L. Van Hekken, F. J. Molina-Corral, P. M. Tomasula, J. Call, J. Luchansky, and A. A. Gardea. 2008. Queso Chihuahua: Manufacturing procedures, composition, protein profiles, and microbiology. Int. J. Dairy Technol. 61:62-69.

Van Hekken, D. L., M. A. Drake, F. J. Molina-Corral, V. M. Guerrero Prieto, and A. A. Gardea. 2006. Mexican Chihuahua cheese: Sensory profiles of young cheese. J. Dairy Sci. 89:3729-3738.

Walstra, P., J. T. M. Wouters, and T. J. Geurts. 2006. Dairy Science and Technology. 2nd ed. CRC Press, Boca Raton, FL. 